\title{
КОНЦЕПТУАЛЬНІ ЗАСАДИ ДУХОВНОГО РОЗВИТКУ ОСОБИСТОСТІ НАУКОВО-ПЕДАГОГІЧНОГО ПРАЦІВНИКА ЗАКЛАДУ ВИЩОЇ ОСВІТИ
}

\begin{abstract}
Ступінь духовної культури слугує мірилом фахової компетентності. Тільки завдяки глибинному розумінню морально-етичних засад гуманного суспільства особистість зможе обрати вірний шлях до розвитку цьього суспільства. Особливу роль у моральному складнику наукової діяльності педагога-вченого посідає його ставлення до релігії. Взаємини поміж наукою й релігією непрості. Невипадково усе більшого значення науковці надають проблемі духовності фахівия, ї̈ психологічному змісту, механізмам становлення. Теперішня фахова освіта практично не забезпечує морального самовизначення особистості. В статті обтрунтовано концептуальні засади духовного розвитку особистості науково-педагогічних працівників закладів вищої освіти в контексті гуманістичної парадигми освіти й науки. Окреслені у статті позиції стисло регламентуються концептуальними засадами розвитку духовності науково-педагогічних прачівників, згідно з якими особистість формується на базі гуманістичних ідей сучасного суспільства, як-от: 1) иілісність розвитку особистості науково-педагогічних працівників з изіннісно-мотиваційною домінантою, яка концентрує інструментальні властивості, гармонізує всі аспекти його діяльності; 2) поєднання загального, фахового й індивідуалізованого розвитку особистості з урахуванням їх істотного впливу на розвиток індивіда; 3) формування духовної культури науково-педагогічних працівників як усвідомлення духовного виміру науково-педагогічної діяльності; 4) національна гідність вченого як складника духовної культури, щзо має свою історичну специфіку з неповторними, притаманними для конкретної нації рисами; 5) єдність науки та освіти, щьо базується на тенденціях розвитку наукової практики викладача (взаємний зв'язок досвіду наукової й педагогічної роботи; повсякчасне збагачення змісту, форм і методів наукової праці педагога та його науково-дослідної діяльності тощь); 6) урахування раннього початку розвитку, побудоване на основі первісного фахового та педагогічного досвіду та подальших змін, на які впливають освіта, життєвий $i$ фаховий досвід людини, ї̈ самовдосконалення тощо; 7) иілепокладання фахових знань, усвідомлення, в ім'я чого їх здобувають, куди веде знання і який результат його реалізаиії в житті та професійній діяльності особистості.

Ключові слова: концептуальні засади, духовний розвиток, особистість, науково-педагогічні працівники, заклади вищої освіти
\end{abstract}

\author{
Yurii KOZLOVSKII, \\ orcid.org/0000-0003-1006-0130 \\ Doctor of Science in Pedagogy, Assistant Professor, \\ Head of Pedagogy and Innovative Education Department \\ Lviv Polytechnic National University \\ (Lviv, Ukraine) yuriy.m.kozlovskiy@lpnu.ua
}

\section{CONCEPTUAL FUNDAMENTALS FOR PERSONAL SPIRITUAL DEVELOPMENT OF THE SCIENTIFIC AND PEDAGOGICAL STAFF OF HIGHER EDUCATION ESTABLISHMENTS}

The level of spiritual culture is a criterion of professional competence. Only due to deep comprehension of the moralethic fundamentals of a humane society, a personality is able to choose the right way of the society development. The attitude to religion is of particular importance in the moral component of the scientific activity of a scientist and educator. The relations between the science and religion are very complicated. Therefore, the problem of the spiritual culture of specialists, its psychological content, mechanism of formation is currently of specific concern. Nowadays, professional education almost ignores the personal moral self-determination. Substantiation of the conceptual fundamentals of personal spiritual development of the scientific and pedagogical staff of higher education establishments in context of the humanistic paradigm of education and science. The ideas, described in the article, regulate the conceptual fundamentals of the scientific and pedagogical staff development. According to them, a personality is developed on the basis of humanistic ideas of modern society: 1) integrity of personal development of the scientific and pedagogical staff with a value-motivating dominant, which concentrates instrumental properties, harmonizes all aspects of its activity; 
2) combination of general, professional and individual development of a personality with consideration of its significant impact on the individual growth; 3) formation of spiritual culture of the scientific and pedagogical staff as realization of the spiritual criterion of its scientific and pedagogical activity; 4) scientist's national dignity as a component of spiritual culture, which has its historical specificity and the features, which are unique for the nation; 5) unity of the science and education that is based on the tendencies of development of the teacher's scientific practice (interrelation between the experience of the educator's scientific and pedagogical work, continuous enrichment of the content, forms and methods of the educator's scientific work and his/her research activity, etc.); 6) consideration of the early start of development, based on the primary professional and pedagogical experience and following changes, influenced by education, life and professional experience, self-determination, etc.; 7) goal setting of the professional knowledge, comprehension of the reason of knowledge obtaining and what results they should provide in the life and in the professional activity of the personality.

Key words: conceptual fundamentals, spiritual development, scientific and pedagogical staff, higher education establishments

Постановка проблеми. У розвитку особистості завдяки морально-духовним засадам можливе забезпечення міцного підгрунтя для розвитку свідомого громадянина. У житті кожної особистості настає мить, коли вона прагне самотужки впевнитись у правдивості положень, покладених в основу іiі буття. На цій стадії допомагає наука, що слугує цілеспрямованою діяльністю для здобуття знань, точної інформації щодо явища й предметів пізнання. Духовним розвитком індивіда передбачено низку видів людської діяльності, зокрема наукову, яка має важливе значення для формування духовної культури. Загалом наукова діяльність грунтується на знаннях, що дають змогу людині правильно оцінювати довкілля, послуговуючись перевіреними фактами, долучитися до розвитку науки, країни або суспільства.

Духовність, що $є$ якісною характеристикою свідомості з визначення дій людини, ії вчинків, життя, - прикмета людини як суб'єкта, на відміну від бездуховності (втрата суб'єктивних рис і перетворення на простий об'єкт). Відтак і тлумачать духовність як поступову актуалізацію особистістю їі суб'єктних рис (Чернілевський, Пшеничнюк, Сідячева, 2009: 35). В аксіологічному аспекті традиційні складники духовності - істина, добро, краса. Досягнення - іiі основне завдання, яке виникає перед особистістю в житті.

Водночас людина є єдиною у світі істотою, спроможною пізнавати цей світ сповна. Такі погляди спільні як для науковців, так і для богословів. Згідно із християнством людину створено за Господніми образом і подобою, їй надано свободу, й у неї $\epsilon$ особливе призначення - творити й пізнавати, відповідаючи при цьому перед Богом за власне господарювання на Землі (Свідзинський, 2009: 414).

Готуючись до фахової праці, треба неабияку увагу приділяти становленню гармонійного й креативного індивіда, найкращому втіленню його можливостей, прояву індивідуальності в різних життєвих сферах. Невипадково усе більшого значення науковці надають проблемі духовності фахівця, іiі психологічному змісту, механізмам становлення. Людина розкриває закономірності функціонування зовнішнього для нього світу та створює нові можливості для використання розмаїття структур, віднайдених у світі, чим полегшує або, навпаки, ускладнює умови власного буття. Окрім того, люди пізнають і самих себе, власні обов'язки перед Усевишнім, природою, спільнотою й особистістю зокрема. Лише гуманітарні знання, мистецтво та релігія вміщують складники самооцінки людей, а це - основа для усвідомлення потрібних самообмежень на всю їхню діяльність, зокрема й науково-технічну.

Аналіз досліджень. Існують пропозиції «розглянути три аспекти функціонування педагогіки в академічній сфері, перші два, що ведуть до іiі відносної «інвалідності», руйнування або аномалії з негативними наслідками цього процесу. Схожість умов наукової роботи та академічної позиції педагогів не забезпечують автоматичного їхнього співробітництва в останній з пропонованих вимірів педагогіки - педагогіки надії чи надії, пов'язаної з педагогікою» (Śliwerski, 2017: 8). Загалом цей автор намагається прокласти шлях від педагогіки безнадії до педагогіки надії, вказуючи на такі небезпеки, як фундаменталізм у педагогіці (хоча в інших науках він відіграє часто позитивну роль) та надання педагогіці службової ролі в освіті.

Грунтовний аналіз духовної культури особистості проведено Чернілевським (2009). Основи гуманізації освіти як запоруки виховання творчої та духовно багатої особистості закладені Гончаренком (2004). Прогностичні аспекти та обрії педагогіки майбутнього аналізуються у роботах Вознюка (2019) та Сліверського (2017). Значну роль у розвитку теорії духовності особистості відіграє синергетична парадигма, культурологічний аспект якої викладено у класичній праці Свідзинського (2009). Сьогодні досліджуються проблеми становлення особистості, що є вкрай складним комплексом, сформованим із десятків 
складників, утім проблему особистісного розвитку науково-педагогічних працівників досліджено ще недостатньо.

Мета статті - обгрунтування концептуальних засад духовного розвитку особистості науковопедагогічних працівників закладів вищої освіти в контексті гуманістичної парадигми освіти й науки.

Виклад основного матеріалу. Ступінь духовної культури слугує мірилом фахової компетентності людини. Це викликано тим, що наукове знання, слугуючи потужним інструментом, може бути як надзвичайно корисним, так і руйнівним. Тільки завдяки глибинному розумінню моральноетичних засад гуманного суспільства особистість зможе обрати вірний шлях до розвитку цього суспільства. Здобувши певні знання, людина як сформована особистість береться послуговуватися ними й передавати їх довколишнім.

Готовність до наукової діяльності зазвичай установлюють винятково за раціональними ознаками: кількістю публікацій у наукових виданнях, участю в наукових заходах, внеском у галузеву науку тощо. При цьому оминають увагою найсуттєвіше: моральну значущість наукової діяльності педагога, вплив його наукової позииї й здобутків на викладацьку сторону діяльності. Власне такі аспекти й визначають духовний та виховний вплив педагога на студентів, позаяк його наукове обличчя й педагогічний образ взаємопов'язані.

На наш погляд, фахову компетентність викладача закладу вищої освіти варто розглядати в чотирьох пов'язаних аспектах: педагогічному, галузевому, науковому та моральному.

Особливу роль у моральному складнику наукової діяльності педагога-вченого посідає його ставлення до релігії, позаяк, не знаючи релігії й не розуміючи духовного вимірювання людини, не вдасться опанувати історію власного народу й людства загалом, бо інтегрувальна міць будьякої нації -релігія з ії основною миротворчою функцією (Кукушкін, 2002: 160). Взаємини поміж наукою й релігією дуже непрості. За радянських часів відокремленості релігії від держави таких труднощів не було і все, чого не могла пояснити наука, ігнорували. Тепер погляд на цей зв'язок різко змінився. Відомі вчені в усі часи стверджували, що логічний метод пізнання не єдиний $-\epsilon$ ще шлях безпосереднього споглядання, який проникає в сутність явищ. Для людини притаманне, окрім раціонального, ще й ірраціональне знання, яке грунтується на відчутті, а не на міркуванні.

Тож педагог, поєднуючи педагогічні й наукові функції, маєвирішуватидлясебе,поприпедагогічні та галузеві, істотні морально-релігійні питання.
Зауважимо, що в такому разі проблема вкрай складна, позаяк педагог наштовхується не тільки на проблеми науки педагогіки, а й проблеми галузевої науки, визначеної профілем закладу освіти: економіка, фізика, будівництво, історія тощо.

Дослідник Гончаренко (2005) вважає, що запорука успіху під час формування духовно збагаченої, творчої особистості - гуманізація освіти, якою передбачено посилену увагу до індивіда, забезпечення найсприятливіших умов для його становлення й поступу. Замінити технократичний виклик людству мають гуманістична парадигма або орієнтація. Теперішня фахова освіта практично не забезпечує майбутньому фахівцеві його морального самовизначення, не покращує етичну оцінку розроблюваних технічних ідей. Система масової освіти не зорієнтована на те, аби учні спрямовували власні зусилля на формування навичок самовдосконалення, індивідуальності, пов'язування самопізнання із самовизначенням, а особисті заняття - із загальнокультурними цінностями.

Такий самий стан і з іншими галузями освітньої й наукової діяльності, в яких учень, студент або молодий науковець здобуває інформацію без морально-етичної оцінки, а сам зазвичай оцінити неспроможний. Отож, розвиток особистості науково-педагогічних працівників має грунтуватися на певних засадах, цілісним додержанням яких передбачено формування морально-етичного складника наукової діяльності.

Послуговуючись загальними принципами розвитку людини, які пропонує О. Столяренко (2006), керуючись ідеями Гончаренка (2005) та результатами, отриманими нами в роботі (Козловський: 2009), ми доповнили, узагальнили та конкретизували їх як умови розвитку індивіда науково-педагогічних працівників в контексті гуманістичної парадигми освіти та науки.

Наукова діяльність - тільки один складник непростої структури розвитку індивіда. Процес розвитку властивостей, поряд із науковим складником, передбачає освіту, виховання, релігію, мистецтво тощо. Поволі прямуючи в одному напрямі, людські якості постійно зростають, підтримуючи одна одну. Кволий розвиток або відсутність якоїсь якості негативно позначаються на інших, порушуючи цілісність людського розвитку.

Кожному фаху або групі споріднених спеціальностей відповідає провідна для неї цілісна особистісна якість, і власне ії розвитку варто приділяти найбільше уваги. Основа такої якості, духовний стрижень особистості фахівця - певна ціннісно-мотиваційна домінанта. Наприклад, для особистості вченого це спрямування на пошук 
правди (раціонально обгрунтований спосіб, прийнятний для наукової спільноти); для особистості інженера - намагання створити найдосконаліший технічний об'єкт чи бодай забезпечити його найефективнішу діяльність); для особистості митця - намагання вираження істотних для нього сенсів у художніх образах і залучення до таких сенсів людей, що сприйматимуть його твори. Довкола такої домінанти сконцентровано інструментальні властивості, потрібні для втілення певного спрямування особистості, також складники зазначеної єдиної якості (Чернілевський, Пшеничнюк, Сідячева, 2009).

Отож, єдність розвитку індивіда - основний принцип становлення науково-педагогічних працівників, гармонізації всіх аспектів його функціонування.

Принцип єдності дає змогу виокремити загальні складники розвитку, характерні для кожної особистості, утім не враховує їхньої індивідуальності. Однак фахове спрямування та індивідуальність істотно впливають на розвиток індивіда. Для кожного науково-педагогічного працівника характерні індивідуальні погляди гуманізації, утім, групуючись, вони утворюють певні морально-етичні норми, які своєю чергою допомагають цілісно розвиватися.

Із посиленою підготовкою людини до фахової діяльності виникає потреба і в розвитку відповідного хисту. То не лише розвиток рис, яким досі не приділяли істотної уваги, а й професіоналізація частки уже набутих, як-от фахових спостережливості, пам'яті, мислення тощо. Причому останне відбувається стрімкіше й успішніше (за один термін - близько утричі) за перше. Удача, здобуття помітних позитивних результатів переважно надихають людину продовжувати й удосконалюватися у фаховому саморозвитку. Індивідуалізація розвитку відповідає також задоволенню людської потреби бути унікальною. Це також корисно для функціонування груп із людей, котрі несуттєво різняться заздібностями і працюють гірше за групи індивідуально специфічних особистостей із загальними груповими інтересами й цінностями (Столяренко, 2006).

На початку формування особистості, під час навчання, спостерігаємо максимальний вплив принципів загального розвитку, тобто людина одержує інформацію стосовно загальних тенденцій і перспектив. Це коло істотно меншає на початку наукової діяльності, зі своїми пріоритетами й особливостями. На цій стадії також формуються риси особистісного розвитку, властиві людині. I лише із завершенням такого процесу розпочинається зворотній процес, тобто узагальнення індивідуальних та фахових рис. Послугову- ючись знаннями зі школи, закладу вищої освіти й аспірантури, особистість, сформувавши фахові риси, передає здобуті навички молоді. У цей час украй важливо разом із власне фаховими навичками передати учням морально-духовні засади та етичні норми власного фаху.

Усвідомлення духовного виміру наукової проблеми - необхідний етап ії повного вирішення, бо інакше проблему буде вирішено не повністю або некоректно.

Філософи й суспільствознавці сьогодні дискутують на тему походження, становлення та подальшого розвитку духовності. Звісно, йдеться про просте ототожнення духовності й релігійності. Найважливіше 3-поміж усього для виховної мети, вочевидь, те, що духовність виокремлює 3-поміж людських потреб дві фундаментальні: потреба пізнання, яка спонукає не обмежуватися наявними знаннями, i соціальна альтруїстична потреба, що стимулює дії людини «для інших» (Вознюк, 2019). Сутність гуманізації («олюднення») вказує на те, що вона зачіпає зміни не тільки змісту, а й методів освіти, скеровуючи їх на активний розвиток особистості учня.

Виникає питання щодо значення науки у формуванні духовної культури як індивіда, так і суспільства загалом. Одна зі складників духовної культури - релігія, істотна роль якої це формування світогляду. 3 давніх-давен в Україні такою релігією було й є християнство, в основу якого покладено віру в єдиного Господа - Творця. На перший погляд наука й віра - поняття несумісні, позаяк наука грунтується на фактах, а вірою передбачено повну довіру до Творця, що не має точного наукового обгрунтування. Утім, такий конфлікт є тільки на перший погляд, позаяк завдання науки - вичерпне дослідження творіння, аби показати нам мізерність наших знань.

Утім, усі подальші етапи наукового пізнання вказують людині на складніші структури, а елементарні часточки, що впродовж тривалого часу вважали неподільними, нині є окремими системами. Поринаючи у структуру речовини та розуміючи складнощі іiі будови, людина підсвідомо розуміє неможливість самовільного утворення таких структур, зокрема щодо живих організмів.

Зазначене чудово описує датський фізик, природодослідник Ганс Ерстед: «Усяке грунтовне дослідження природи закінчується визнанням існування Бога». Фізик дійшов висновку, що Всесвіт, такий красивий і складний, міг створити тільки Бог. Творцем Усесвіту Господа визнавали чимало видатних науковців, зокрема: А. Вольт, А. Ампер, У. Томпсон, Р. Міллікен, А. Комптон, М. Планк, А. Ейнштейн та інші. 
Отже, здавалося б, логічно: якщо безліч відомих науковців міжнародного рівня, 3-поміж яких навіть нобелівські лауреати, визнавали існування Бога як творця Всесвіту, то конфлікт поміж вірою й наукою відсутній. Як ревні християни науковці тисячоліттями розвивали власні концепції завдяки науці рухатися вперед, виходили на абсолютно нові рівні, з усвідомленою людською вірою.

Отже, власне духовна культура показує основу діяльності науково-педагогічних працівників. Бездумна гонитва за фактами та їхнє групування в теоретичні побудови, необмірковані експерименти над тілом людини під гаслами наукового пізнання - наслідок бездуховності та безвідповідальності прибічників двох найстрашніших спотворень місії науки: науки для науки та науки для політичної чи іншої антигуманної мети.

Адже в категоріях гуманності та богоугодності одна 3 перших заповідей науково-педагогічних працівників - відповідальність за наслідки власних дій. Очевидно, власне такі принципи сповідував відомий на весь світ учений $\mathrm{H}$. Тесла, який знищив деякі власні винаходи, що, на його думку, суттєво випереджували духовні запити людей і могли завдати йому непоправної шкоди. Відмова від світового визнання, від возвеличення власного наукового «Я» заради безпеки й збереження людства $€$ прикладом духовного осмислення наслідків наукового відкриття. Хай як це неприємно й боляче, сповільнює науково-технічний прогрес, утім, сьогодні технічний розвиток людства настільки попереду духовного, що зазначені обмеження дуже потрібні. Це потребує наукової сміливості - однієї з паростків духовності новітнього науково-педагогічних працівників.

Наукові розвідки як складник духовної культури мають свою історичну специфіку 3 неповторними, притаманними для конкретної нації рисами, зокрема йдеться про гуманітарні науки. Учений під час творчої діяльності грунтується не тільки на наукових фактах, а й на духовно-етичних чинниках, характерних його країні.

У контексті поданої цитати логічним буде питання: які ж асоціації з'являються в науковців щодо України? Майже всі вони - або зарубіжні вчені українського походження, або потрібно доводити їхню першість у науці. Це закономірність нації, яка упродовж століть не мала державності. Тож зостається сподіватися, що в майбутньому ситуація покращиться.

Поєднуючи загальний, фаховий та індивідуалізований розвиток, на якомусь етапі науковець розпочинає передавати свої знання молоді. В академічній установі такий процес починається з аспі- рантури, коли особистість уже достатньо сформована. Цілісність університетських освіти та науки забезпечує вченому змогу спілкуватися зі студентами вже на першому курсі, відтак значно раніше розпочинається процес формування духовної культури та наукової діяльності як іiї складника.

У нинішньому відкритому суспільстві, вважає Л. Колаковський (2005), функціями університету мають бути: забезпечення в обмеженому сенсі фахової освіти вищого рівня, діяльність на постійне примноження культури, збагачування наших знань про світ. Послуговуючись зазначеними фактами, Свідзинський (2009) стверджує, для власне університетської науки з'являються додаткові стимули розвитку раннім залученням найздібніших студентів до наукової роботи.

Сьогодні ми все частіше стикаємося зі штучно створеними науковими школами, очолюваними людьми 3 потужними адміністративними перспективами, але без жодного стосунку до науки. Водночас великі вчені не мають змоги розвивати власні школи через брак коштів.

У розвитку наукової школи морально-релігійні питання відіграють украй важливу роль, передусім визначаючи ціль діяльності (суто наукова чи прагматична), регулюючи особисті амбіції членів школи (вирішення питання: «я для науки» або «наука для мене»). Вирішення таких питань для студентів неабияк впливає на їхню майбутню фахову діяльність. I, власне, викладач, що слугує і педагогом, і науковцем, істотно впливає на те, якими саме шляхами в майбутньому підуть його студенти.

Формувати духовну культуру, зокрема наукову діяльність, варто якнайшвидше, аби по завершенню закладу вищої освіти молода людина мала чітко визначений напрям фахової діяльності та сформовані морально-етичні переконання. Генетичні та психофізіологічні передумови розвитку актуальні людині у 22-24 роки. Педагог повинен знати ступінь такого розвитку, намагаючись поліпшити необхідне, надати допомогу, що полягає передусім у тому, щоб показати людині особливості іiі розвитку, спонукати вдосконалюватись, як-от в освітньому чи трудовому процесі, навчити цьому.

Висновки. Таким чином, концептуальні засади розвитку науково-педагогічних працівників полягають у такому: цілісності розвитку особистості науково-педагогічних працівників 3 ціннісно-мотиваційною домінантою, яка концентрує інструментальні властивості, гармонізує всі аспекти його діяльності; поєднання загального, фахового й індивідуалізованого розвитку особистості з урахуванням їх істотного впливу на розви- 
ток індивіда; формування духовної культури науково-педагогічних працівників як усвідомлення духовного виміру науково-педагогічної діяльності; національної гідності вченого як складника духовної культури, що має свою історичну специфіку з неповторними, притаманними для конкретної нації рисами; єдності науки та освіти, що базується на тенденціях розвитку наукової практики викладача (взаємний зв'язок досвіду наукової й педагогічної роботи; повсякчасне збагачення змісту, форм і методів наукової праці педагога та його науково-дослідної діяльності тощо); ура- хування раннього початку розвитку, побудоване на основі первісного фахового та педагогічного досвіду та подальших змін, на які впливають освіта, життєвий і фаховий досвід людини, ii самовдосконалення тощо; цілепокладання фахових знань, усвідомлення, в ім'я чого їх здобувають і куди веде знання, і який результат його реалізації в житті та професійній діяльності особистості.

Подальшими напрямами дослідження є теоретико-методологічне обгрунтування доцільності, можливості та шляхів релігійного виховання студентської молоді.

\section{СПИСОК ВИКОРИСТАНИХ ДЖЕРЕЛ}

1. Вознюк А. В. Постнеклассические рубежи педагогики будущого : учеб. пособ. Житомир : Koob publications, 2019. $1149 \mathrm{c}$.

2. Гончаренко С. Гуманізація освіти - запорука виховання творчої та духовно багатої особистості. Дидактика професійної школи : зб. наук. пр. Хмельницький : ХНУ, 2005. Вип. 3. С. 19-23.

3. Козловський Ю. М. Наукова діяльність викладача вищого навчального закладу: морально-релігійний аспект. Проблеми освіти: спец. випуск. Духовно-моральне виховання і професіоналізм особистості в сучасних умовах. 2009. С. 119-124.

4. Колаковський Л. Мої правильні погляди на все. Київ : Видавничий дім «Києво-Могилянська академія», 2005. 32 c.

5. Кукушкин В. С. Теория и методика воспитательной работы : учеб. пособ. Ростов н/Д : МарТ, 2002. 320 с.

6. Свідзинський А. В. Синергетична концепція культури. Луцьк : ВАТ «Волинська обласна друкарня», 2009. 696 с.

7. Столяренко А. М. Общая педагогика. Москва : ЮНИТИ-ДАНА, 2006. 479 с.

8. Чернілевський Д. В., Пшеничнюк О. В., Сідячева Н. В. Духовна культура особистості : навч. посіб. КиївВінниця : Академія креативної педагогіки, 2009. 384 с.

9. Śliwerski В. Pedagogika przyszłości. Освітологія. 2017. № 6. С. 8-19.

\section{REFERENCES}

1. Vozniuk A. V. Postneoklassicheskie rubezhi pedagogiki budushchego [Post neoclassical targets of the pedagogics in the future]. Manual. Zhytomyr: Koob publications, 2019, 1149 p. [in Russian].

2. Honcharenko S. Humanizatsiia osvity - zaporuka vykhovannia tvorchoii ta dukhovno bahatoii osobystosti [Education humanization - a key to educating a creative and spiritually rich personality]. Didactics of professional school: collection of scientific works. Khmelnytskyi: KhNU, 2005, Iss. 3, pp. 19-23 [in Ukrainain].

3. Kozlovskyi Yu. M. Naukova diiialnist vykladacha vyshchoho navchalnoho zakladu: moralno-relihiinyi aspect [Scientific activity of a high school teacher: moral and religious aspect]. Problems of education: special edition. Spiritual and moral education and professionalism of a personality in the modern conditions, 2009, pp. 119-124 [in Ukrainian].

4. Kolakovskyi L. Moii pravylni pohliady na vse [My adequate ideas concerning everything]. K.: Publishing house "Kyievo-Mohylianska akademiia", 2005, 32 p. [in Ukrainian].

5. Kukushkin V. S. Teoriia i metodika vospitatelnoi raboty [Theory and methodology of educational work]: manual. Rostov n/D: MarT, 2002, 320 p. [in Russian].

6. Svidzynskyi A. V. Synerhetychna kontseptsiia kultury [Synergetic concept of culture]. Lutsk: OJSC "Volynska oblasna drukarnia", 2009, 696 p. [in Ukrainain].

7. Stoliarenko A. M. Obshchaia pedahohika [General pedagogics]. M.: YuNITI-DANA, 2006, 479 p. [in Russian].

8. Chernilevskyi D. V., Pshenychniuk O.V., Sidiacheva N.V. Dukhovna kultura osobystosti [Spiritual culture of a personality]: manual. Kyiv-Vinnytsia: Akademia kreatyvnoii pedahohiky, 2009, 384 p. [in Ukrainain].

9. Śliwerski B. Pedagogika przyszłości [Pedagogics of the future]. Educology, 2017, Nr 6, pp. 8-19 [in Polish]. 